\title{
MANAGEMEN UNTUK MENCEGAH KOMPLIKASI JANGKA PANJANG PENYAKIT DIABETES MELITUS
}

\author{
Ponudurai. $P$ \\ Fakultas Kedokteran Universitas Udayana \\ (drprabu89@gmail.com)
}

\begin{abstract}
Abstrak
Diabetes mellitus (DM) adalah gangguan metabolisme yang progresif kronis yang ditandai dengan hiperglikemia terutama disebabkan absolut (Type 1 DM) atau relatif (Tipe 2 DM) hormon insulin defisiensi . Perkiraan Organisasi Kesehatan Dunia bahwa lebih dari 346 juta orang di seluruh dunia menderita DM. Jumlah ini kemungkinan akan lebih dari dua kali lipat pada tahun 2030 tanpa intervensi. Kebutuhan pasien diabetes tidak hanya terbatas pada kontrol glikemik yang memadai, tetapi juga sesuai dengan mencegah komplikasi; Keterbatasan cacat dan rehabilitasi. Ada tujuh perawatan diri penting perilaku pada penderita diabetes yang memprediksi hasil makan makanan yang sehat, aktif secara fisik, pemantauan gula darah, pengobatan yang teratur, kemampuan menyelesaikan masalah yang baik, keterampilan gaya hidup sehat dan perilaku pengurangan risiko diabetes. Semua tujuh perilaku ini telah ditemukan berkorelasi positif dengan glikemik yang baik dari segi kontrol, pengurangan komplikasi dan peningkatan kualitas hidup. Individu dengan diabetes telah memainkan peranan penting pada perkembangan dan perkembangan penyakit mereka dengan berpartisipasi dalam perawatan mereka sendiri.Beberapa demografis, faktor dukungan sosial-ekonomi dan sosial dapat dianggap sebagai kontributor positif dalam memfasilitasi aktivitas perawatan diri pada pasien diabetes, peran dokter dalam mempromosikan perawatan diri adalah penting dan harus ditekankan.
\end{abstract}

Kata kunci: Diabetes, perawatan diri, aktivitas fisik, Modifikasi gaya hidup

\section{PENDAHULUAN}

Diabetes mellitus (DM) merupakan gangguan kronis progresif metabolic, gangguan yang ditandai dengan hiperglikemia terutama disebabkan mutlak (DM tipe 1) atau relatif (Tipe 2 DM) kekurangan Hormon insulin. DM hampir mempengaruhi setiap sistem tubuh karena gangguan metabolisme yang disebabkan oleh hiperglikemia, terutama jika diabetes kontrol selama periode waktu terbukti suboptimal. Sampai saat ini penyakit ini dianggap sebagai penyakit yang terjadi negara maju, namun temuan baru mengatakan dengan kenaikan jumlah kasus baru DM tipe 2 sebagai onset awal dan terkait komplikasi di negara berkembang . Komplikasi diabetes adalah seperti kardiovaskuler penyakit, nefropati, retinopati dan neuropati, yang dapat menyebabkan morbiditas kronis dan kematian. Organisasi Kesehatan Dunia (WHO) memperkirakan bahwa lebih dari 346 juta orang di seluruh dunia menderita DM. Jumlah ini adalah cenderung lebih dari dua kali lipat pada tahun 2030 tanpa intervensi. Hampir $80 \%$ kematian terjadi pada diabetes adalah negaranegara berpenghasilan rendah dan menengah. Menurut laporan WHO, India saat ini munpunyai jumlah terbesar di dunia dengan lebih dari 32 juta pasien diabetes dan jumlah ini diprediksikan meningkat menjadi 79,4 juta pada tahun 2030.

\section{DEFINISI}

Diabetes Melitus Diabetes Melitus adalah penyakit kelainan metabolik yang dikarakteristik an dengan hiperglikemia kronis serta kelainan metabolisme karbohidrat, lemak dan protein diakibatkan oleh kelainan sekresi insulin, kerja insulin maupun keduanya.2 Hiperglikemia kronis pada diabetes melitus akan disertai dengan kerusakan, ganguan fungsi beberapa organ tubuh khususnya mata, ginjal, saraf, jantung, dan pembuluh darah. Walaupun pada diabetes melitus ditemukan ganguan metabolisme semua sumber makanan tubuh kita, kelainan metabolisme yang paling utama ialah kelainan metabolisme karbohidarat. Oleh karena itu diagnosis diabetes melitus selalu berdasarkan tinginya kadar glukosa dalam plasma darah. 4

Prevalensi DM sulit ditentukan karena standar penetapan diagnosisnya berbeda-beda. Berdasarkan kriteria American Diabetes Asociation tahun 2012 (ADA 2012), sekitar 10,2 juta orang di Amerika Serikat menderita DM. Sementara itu, di Indonesia prevalensi DM sebesar 1,52,3\% penduduk usia >15 tahun, bahkan di daerah 
Manado prevalensi DM sebesar 6,1\%.3 Pemeriksan laboratorium bagi penderita DM diperlukan untuk menegakan diagnosis serta memonitor terapi dan timbulnya komplikasi. Dengan demikian, perkembangan penyakit bisa dimonitor dan dapat mencegah komplikasi.3

\section{KLASIFIKASI}

Diabetes Melitus DM adalah kelainan endokrin yang ditandai dengan tinginya kadar glukosa darah. Secara etiologi DM dapat dibagi menjadi DM tipe 1, DM tipe 2, DM dalam kehamilan, dan diabetes tipe lain.2,3,4,5 DM tipe 1 atau yang dulu dikenal dengan nama Insulin Dependent Diabetes Melitus (IDDM), terjadi karena kerusakan sel $\beta$ pankreas (reaksi autoimun). Sel $\beta$ pankreas merupakan satu-satunya sel tubuh yang menghasilkan insulin yang berfungsi untuk mengatur kadar glukosa dalam tubuh. Bila kerusakan sel $\beta$ pankreas telah mencapai $80-90 \%$ maka gejala DM mulai muncul. Perusakan sel ini lebih cepat terjadi pada anak-anak daripada dewasa. Sebagian besar penderita DM tipe 1 sebagian besar oleh karena proses autoimun dan sebagian kecil non autoimun. DM tipe 1 yang tidak diketahui penyebabnya juga disebut sebagai type 1 idiopathic, pada mereka ini ditemukan insulinopenia tanpa adanya petanda imun dan mudah sekali mengalami ketoasidosis. DM tipe 1 sebagian besar (75\% kasus) terjadi sebelum usia 30 tahun dan DM Tipe ini diperkirakan terjadi sekitar 5-10\% dari seluruh kasus DM yang ada.3,4,5 DM tipe 2 merupakan 90\% dari kasus DM yang dulu dikenal sebagai non insulin dependent Diabetes Melitus (NIDDM). Bentuk DM ini bervariasi mulai yang dominan resistensi insulin, defisiensi insulin relatif sampai defek sekresi insulin.3,4 Pada diabetes ini terjadi penurunan kemampuan insulin bekerja di jaringan perifer (insulin resistance) dan disfungsi sel $\beta$. Akibatnya, pankreas tidak mampu memproduksi insulin yang cukup untuk mengkompensasi insulin resistance. Kedua hal ini menyebabkan terjadinya defisiensi insulin relatif. Kegemukan sering berhubungan dengan kondisi ini. DM tipe 2 umumnya terjadi pada usia $>40$ tahun. Pada DM tipe 2 terjadi ganguan pengikatan glukosa oleh reseptornya tetapi produksi insulin masih dalam batas normal sehinga penderita tidak tergantung pada pemberian insulin. 3 Walaupun demikian pada kelompok diabetes melitus tipe-2 sering ditemukan komplikasi mikrovaskuler dan makrovaskuler.4 DM dalam kehamilan (Gestational Diabetes Melitus - GDM) adalah kehamilan yang disertai dengan peningkatan insulin resistance (ibu hamil gagal mempertahankan euglycemia).3 Pada umumnya mulai ditemukan pada kehamilan trimester kedua atau ketiga.4 Faktor risiko GDM yakni riwayat keluarga DM, kegemukan dan glikosuria. GDM meningkatkan morbiditas neonatus, misalnya hipoglikemia, ikterus, polisitemia dan makrosomia. Hal ini terjadi karena bayi dari bu GDM mensekresi insulin lebih besar sehinga merangsang pertumbuhan bayi dan makrosomia. Kasus GDM kira-kira 3-5\% dari ibu hamil dan para ibu tersebut meningkat risikonya untuk menjadi DM di kehamilan berikutnya.3 Subkelas DM lainya yakni individu mengalami hiperglikemia akibat kelainan spesifik (kelainan genetik fungsi sel beta), endokrinopati (penyakit Cushing's, akromegali), pengunan obat yang mengangu fungsi sel beta (dilantin), pengunan obat yang mengangu kerja insulin (b-adrenergik) dan infeksi atau sindroma genetik (Down's, Klinefelter's).3

\section{PERAWATAN DIRI}

Kesadaran diri dalam diabetes didefinisikan sebagai suatu proses pengembangan pengetahuan atau kesadaran dengan mendapatkan informasi untuk mengatasi dan melawan gejala- gejala kompleks diabetes. Karena sebagian besar perawatan sehari-harian pada pasien dengan diabetes ditangani oleh pasien sendiri dan atau keluarga, memainkan peranan penting bagi menangani dan mengatasi diabetes pada perawatan diri diabetes. Terdapat tujuh perilaku perawatan diri penting pada orang dengan diabetes yang mendapat hasil yang baik iaitu gaya hidup makan makanan sehat, aktif secara fisik, pemantauan darah gula, pengobatan yang teratur, kemampuan menyelesaikan masalah yang baik, keterampilan gaya hidup sehat dan perilaku pengurangan risiko diabetes. Pada pasien diabetes, perawatan diri adalah satu perilaku yang harus ditampilkan oleh pasien sendiri yang menpunyai faktor risiko diabetes bagi merawat oenyakit mereka sendiri. Semua tujuh perilaku telah ditemukan berkorelasi dengan kontrol glikemik yang baik, pengurangan komplikasi dan peningkatan kualitas hidup. Selain itu, perawatan diri dikatakan meliputi tidak hanya melakukan kegiatan ini tetapi juga keterkaitan antara perilaku tersebut . Perawatan diri diabetes memerlukan pasien untuk membuat banyak modifikasi diet dan gaya hidup diikuti dengan peran tenaga medis untuk menjaga tingkat yang lebih optimal dari kepercayaan diri yang mengarah ke suksesan pada perubahan perilaku .Dari segi pendidikan manajemen diri diabetes meskipun genetika memainkan peran penting dalam pengembangan diabetes, studi kembar monozigot memiliki pasti menunjukkan pentingnya pengaruh lingkungan. Individu dengan diabetes telah terbukti mendapat dampak yang positif pada perkembangan dan pengembangan penyakit mereka dengan berpartisipasi dalam perawatan mereka sendiri. Partisipasi dapat 
berhasil hanya jika mereka menyediakan pelayanan kesehatan yang efektif bagi merawat penyakit. Mereka yang pengetahuan terbesar diharapkan akan memiliki pemahaman yang lebih baik tentang penyakit dan memiliki dampak yang lebih baik pada perkembangan penyakit dan komplikasi. Asosiasi Amerika Endokrin menekankan pentingnya pasien menjadi aktif dan peserta memiliki pengetahuan dalam perawatan mereka. Demikian juga, WHO juga telah mengakui pentingnya pasien belajar untuk mengelola diabetes. The American Diabetes Asosiation telah meninjau pendidikan standar diabetes manajemen dan menemukan bahwa ada empat kali lipat peningkatan komplikasi diabetes untuk orangorang yang tidak menerima pendidikan formal mengenai praktek perawatan diri. Pada suatu studi meta analisis perawatan sendiri dengan edukasi pada pasien dewasa dengan diabetes malitus tipe 2 didapati dampat positif pada level glicemic. Satu review mengatakan perawatan sendiri mengunakan edukasi tentang penyakit sendiri telah mengurangkan kadar gula darah mereka.

\section{KESIMPULAN}

Untuk mencegah morbiditas dan mortalitas pada diabetes terkait, kebutuhan yang besar sekali perilaku perawatan diri yang berdedikasi di beberapa domain, termasuk pilihan makanan, aktivitas fisik, obat yang tepat intake dan pemantauan glukosa darah dari pasien. Meskipun beberapa demografis, faktor dukungan sosialekonomi dan sosial dapat dianggap kontributor positif dalam memfasilitasi aktivitas perawatan diri pada pasien diabetes, peran dokter dalam mempromosikan perawatan diri sangat penting dan harus ditekankan. Menyadari sifat multi-faceted masalah, sistematis, multipronged dan pendekatan terpadu diperlukan untuk mempromosikan praktek perawatan diri di antara pasien diabetes untuk mencegah komplikasi jangka panjang.

\section{DAFTAR PUSTAKA}

1. World health organization: Definition, diagnosis and classification of diabetes mellitus and its complications. Geneva: World health organization; 1999.

2. Kinra S, Bowen LJ, Lyngdoh T, Prabhakaran D, Reddy KS, Ramakrishnan L, et al: Sociodemographic patterning of non-communicable disease risk factors in rural India: a cross sectional study. BMJ 2010, 341:c4974.

3. Chuang LM, Tsai ST, Huang BY, Tai TY: The status of diabetes control in Asia-a cross-sectional survey of 24317 patients with diabetes mellitus in 1998. Diabet Med 2002, 19(12):978-985.
4. Narayanappa D, Rajani HS, Mahendrappa KB, Prabhakar AK: Prevalence of pre-diabetes in school-going children. Indian Pediatr 2011, 48(4):295-299.

5. American Diabetes Association: Implications of the United Kingdom Prospective Diabetes Study. Diabetes Care 2004, 27(Suppl 1):28-32.

6. Zucchi P, Ferrari P, Spina ML: Diabetic foot: from diagnosis to therapy. G Ital Nefrol 2005, 22(Suppl 31):S20-S22.

7. World health organization: Diabetes Factsheet. 2012. http://www.who.int/ mediacentre/factsheets/fs312/en/index.html.

8. Mohan D, Raj D, Shanthirani CS, Datta M, Unwin NC, Kapur A, et al: Awareness and knowledge of diabetes in Chennai - The Chennai urban rural epidemiology study. J Assoc Physicians India 2005, 53:283-287.

9. Wild S, Roglic G, Green A, Sicree R, King H: Global prevalence of diabetes: Estimates for the year 2000 and projections for 2030. Diabetes Care 2004, 27(5):1047-1053.

10. Pradeepa R, Mohan V: The changing scenario of the diabetes epidemic: Implications for India. Indian J Med Res 2002, 116:121-132. 